\title{
Evaluasi Pengendalian Internal Sistem Informasi Akuntansi Penerimaan Kas Pada PT Bank BRI Cabang Tahuna
}

\author{
Debby E. R. Sarapi \\ Wilfried S. Manoppo \\ Dantje Keles

\begin{abstract}
Jurusan Ilmu Administrasi, Program Studi Administrasi Bisnis, Fakultas Ilmu Sosial dan Politik, Universitas Sam Ratulangi debbysarapi97@gmail.com
\end{abstract}

\begin{abstract}
ABSTRACK
Banking has a very important role in the wheel of the Indonesian economy, because it provides services in various business fields. Banking as it is known is not an ordinary business entity as a company engaged in trade and industry, but a business entity engaged in financial services. Internal control within the company is maintaining and ensuring that every activity in the company is in accordance with and in line with the company's goals. With strict internal control, it is expected that all company operations can run smoothly. not only in the case of operations that will run in an orderly and good manner according to the procedure, but from the company's financial perspective it can also be monitored better so that there are no mistakes and acts of fraud. The purpose of this study is to evaluate the internal control and cash receipt accounting systems available at BRI Tahuna Branch. This type of research is qualitative. Methods of data collection in the form, is conducting interviews, observation and documentation. The results of this study are the Implementation of the Internal Control System at Cash Receipts at PT. Bank Rakyat Indonesia (Persero) Tbk Tahuna Branch has fulfilled the elements of the Cash Receipt Internal Control System and is running well. This is indicated by the clear separation of duties, responsibilities, and authority limits in each work unit in the company.
\end{abstract}

Keywords: Internal Control, accounting information systems, Cash Receipts

\section{Pendahuluan}

Dalam perusahaan terdapat sistem informasi akuntansi penjualan dan penerimaan kas, sistem informasi akuntansi penjualan dan penerimaan kas merupakan salah satu subsistem informasi akuntansi yang menjelaskan bagaimana seharusnya prosedur dalam melakukan kegiatan penjualan dan penerimaan kas dari hasil penjualan sehingga tindakan kecurangan terhadap penjualan dan penerimaan kas dapat dihindari. Dengan Sistem informasi akuntansi yang merupakan sistem informasi yang mengolah data keuangan dengan kegunaan, tahap, pengguna dan sumber daya dalam mencakup seluruh kegiatan perusahaan yang akan menghasilkan informasi bagi semua pengguna di perusahaan tersebut (Zuva, dkk, 2013).

Perlu adanya Pengendalian internal yang mengontrol semua rencana organisasi, metode, dan pengukuran yang dipilih oleh kegiatan usaha untuk mengamankan harta kekayaannya, mengecek keakuratan, dan 
keandalan data akuntansi usaha tersebut, dan meningkatkan efisiensi operasional, yang mendukung dipatuhinya kebijakan manajerial yang telah ditetapkan (Hesty, 2013: 7).

Tanpa adanya pengendalian internal sistem informasi akuntansi yang baik perusahaan bisa saja mengalami kerugian yang mengancam perusahaan tersebut karena kecurangan yang tidak terdeteksi maupun kerena pengelolaan sumber daya yang tidak maksimal. Dengan didukung oleh teori Committee Of Sponsoring Organizations (COSO) Susanto (2013: 96) yang memiliki unsur-unsur pengendalian internal yaitu: Lingkungan Pengendalian, penilaian resiko, pengendalian aktivitas, informasi dkomunikasi, dan monitoring yang merupakan rangkaian tindakan yang mencakup keseluruhan proses dalam organisasi yang berada dalam proses manajemen dasar yaitu perencanaan, pelaksanaan, dan pemantauan, akan membuat suatu perusahaan tersebut menjadi perusahaan yang berjalan dengan baik. Oleh kerena itu, pada dasarnya perusahaan baik besar maupun kecil, perlu memperhatikan dan memahami cara pengendalian internal sistem informasi akuntansi (SIA) penerimaan kas.

Pengendalian internal sistem informasi akuntansi juga sangat penting dilakukan oleh PT. Bank Rakyat Indonesia (persero), Tbk Cabang Tahuna agar menghasilkan tujuan perusahaan yang efektif dan efisien.
Kegiatan operasional yang dilakukan oleh PT. Bank Rakyat Indonesia (persero), Tbk Cabang Tahuna adalah melaksanakan penyimpanan dana dan peminjaman dana baik secara tunai maupun secara kredit. Banyaknya aktivitas tersebut pada perusahaan menjelaskan sangat penting pengendalian internal sistem informasi akuntansi guna memenuhi kebutuhan keamanan harta kekayaan perusahaan dari tindakan penyelewengan yang dilakukan oleh karyawan perusahaan. Berdasarkan latar belakang penelitian yang telah diuraikan diatas, maka penulis tertarik untuk meneliti dan mengetahui bagaimana sebenarnya pengendalian internal sistem informasi akuntansi penerimaan kas pada PT. Bank Rakyat Indonesia (persero),Tbk Cabang Tahuna, sehingga penulis tertarik untuk mengangkat sebuah skripsi dengan judul: "Evaluasi Pengendalian Internal Sistem Informasi Akuntansi Penerimaan Kas Pada PT Bank Rakyat Indonesia (persero), Tbk Cabang Tahuna”.

\section{Metode Penelitian}

Dalam penelitian yang dilakukan pada PT.Bank Rakyat Indonesia(persero),Tbk Cabang Tahuna. Penulis menggunakan metode penelitian deskriptif kualitatif yaitu data yang disajikan dalam bentuk wawancara yang dilakukan pada perusahaan ini,dengan melakukan tanya jawab secara langsung dengan pihak yang berwenang atau pihak lain yang 
berhubungan dengan objek yang diteliti untuk mendapatkan informasi tentang pengendalian internal sistem informasi akuntansi penjualan dan penerimaan kas.

Observasi yang dilakukan penulis melalui pengamatan langsung kelapangan dengan cara mencatat segala yang ditemukan dan dapat dijadikan data untuk bahan penulisan skripsi ini yang berhubungan dengan pengendalian internal sistem informasi akuntansi penjualan dan penerimaan kas.

Teknik Dokumentasi yaitu teknik pengumpulan data dengan cara mengumpulkan data-data yang ada dalam perusahaan tempat penelitian.

\section{Hasil Penelitian}

\section{Sistem dan Prosedur Penerimaan Kas}

PT. Bank Rakyat Indonesia Cabang Tahuna dalam praktek pembukuannya pencatatan transaksinya sehari-hari mempergunakan suatu media yang disebut slip. Penjelasan pada slip dibuat sedemikian rupa sehingga memudahkan identifikasi transaksi dan cukup informatif. Slip sebagai media informasi harus mencantumkan keterangan jelas dan dapat dimengerti oleh pihak yang memerlukan baik intern maupun pihak ketiga dalam hal ini nasabah. Keabsahan suatu slip bila dipenuhi beberapa syarat sebagai berikut:

1. Mencantumkan tanggal transaksi.

2. Paraf pejabat bank, teller, dan penyetor.
3. Mencantumkan jumlah uang dengan angka dan huruf untuk slip-slip yang merupakan pembayaran dan penerimaan uang tunai.

Jenis-jenis penerimaan kas khususnya Tabungan pada Bank BRI, antara lain:

1. BritAma

2. Simpedes

3. Simpedes TKI

4. Simpedes Hadiah Langsung

5. Simpedes Impian

6. Tabungan Haji

7. BritAma Dollar

8. BritAma Bisnis

9. BritAma Rencana

10. BritAma Valas

11. BritAma Junio

12. BritAma Man Of Steel

13. TabunganKu

Prosedur penerimaan setoran uang tunai diantaranya:

1. Nasabah mengisi slip setoran yang telah disediakan.

2. Teller menghitung jumlah uang (manual dengan tangan dan menggunakan mesin penghitung uang).

3. Teller mencocokkan jumlah uang dengan nominal yang tertulis di slip setoran.

4. Teller memvalidasi slip setoran menggunakan print passbook.

5. Teller memverifikasi validasi yang sudah tervalidasi / tercetak di slip. 
6. Teller membandingkan dan memeriksa apakah jumlah,tanggal pada slip setoran nasabah sesuai dengan jumlah dan tanggal pada lembar lainnya.

7. Kemudian teller menyerahkan kepada nasabah slip setoran yang sudah di validasi / dibuku ke rekening nasabah.

8. Teller mendistribusikan slip setoran sebagai Lembar bukti nasabah untuk penyetor.

Menurut Susanto, (2013: 96)

Penerapan Sistem Pengendalian Intern atas

Penerimaan Kas terdiri atas :

1. Lingkungan Pengendalian

Semua transaksi uang tunai dengan nasabah hanya dilakukan oleh teller, ditangani dalam ruang teller. Setiap teller akan dilengkapi dengan peralatanperalatan untuk menyimpan uang tunai atau barang-barang berharga lain pada posisi counter-nya.

2. Penaksiran Resiko

Setiap ruang teller dilengkapi dengan pintu dan kunci yang harus tetap terkunci bilamana di dalamnya berisi uang tunai. Hanya orang yang telah diberi wewenang sesuai dengan tugasnya, yang diperbolehkan memasuki ruang teller.

3. Aktivitas Pengendalian

Setiap teller dilengkapi dengan mesin pembuat tanggal / hari (validating machine) dengan cap yang menunjukkan nama unit bank dan nomor teller. Teller akan memberikan perlindungan yang sama terhadap cap ini seperti perlindungan yang diberikan terhadap uang tunai

4. Informasi dan Komunikasi

Setiap bundel uang yang akan disetorkan ke dalam kas besar wajib dihitung secara terperinci terlebih dahulu kemudian wajib diikat dengan pengikat kertas yang tersedia. Pada pengikat kertas tersebut petugas yang menghitung uang wajib membubuhkan parafnya.

5. Pengawasan

Setiap teller wajib memiliki uang pengamanan yang wajib ikut diserahkan bersama uang yang dirampok, Uang pengaman (decoy money) Semua uang tunai, baik di dalam kas utama, lemari besi lain dan kotak uang teller maupun yang ada di dalam perjalanan diasuransikan dari kebakaran, perampokan, dan pencurian.

Pembahasan dalam Evaluasi Penerapan Sistem Pengendalian Intern atas Penerimaan Kas pada PT.Bank Rakyat Indonesia(persero) Cabang Tahuna,antara lain:

1. Lingkungan Pengendalian

Susunan organisasi pada PT. BRI Cabang Tahuna telah menunjukkan adanya pemisahan tugas dan tanggung jawab yang tepat sampai dengan yang diinginkan dalam menciptakan pengendalian kas. 
2. Penaksiran Resiko

Pada perusahaan ini dalam melaksanakan kegiatan operasional bank telah didasarkan pada buku-buku pedoman, memorandum dan instruksi intern manajemen sehingga terciptalah suatu standar operasional unit-unit pada perusahaan tersebut sebagai suatu alat pengendalian.

3. Aktivitas Pengendalian

Alat yang digunakan untuk pengendalin operasi dan transaksi diciptakan melalui perancangan formulir yang tepat. Formulir untuk transaksi penerimaan kas pada perusahaan ini telah dirancang dengan baik dan memenuhi sebagian syarat yang disebut di atas.

4. Informasi dan Komunikasi

Perusahaan ini mempunyai kebijaksanaan mengeluarkan buku pedoman kerja, buku pedoman prosedur akuntansi dan memorandum pelaksanaan prosedur operasi serta instruksi intern lainnya oleh pihak manajemen. Kebiasaan tersebut adalah:

5. Pengawasan

Komite Audit atau di setiap Kantor Cabang BRI disebut juga RAU (Resident Auditor Unit) sebagai penanggung jawab Internal Control untuk mengawasi segala yang berkaitan dengan keuangan khususnya di Bank Rakyat Indonesia(pesero),Tbk Cabang Tahuna. Proses mengawasi pelaksanaan akuntansi keuangan, manajemen, serta perpajakan yang dilakukan oleh tim Auditor setiap 3 bulan sekali.

\section{Kesimpulan}

Kesimpulan yang diperoleh bahwa Penerapan Sistem Pengendalian Intern atas Penerimaan Kas pada PT. Bank Rakyat Indonesia (Persero) Tbk Cabang Tahuna telah memenuhi unsur-unsur Sistem Pengendalian Intern Penerimaan Kas dan berjalan dengan baik. Hal ini ditandai dengan adanya pemisahan tugas, tanggung jawab dan batasan wewenang yang jelas pada setiap unit kerja yang terdapat pada perusahaan, serta perusahaan dipimpin oleh seorang kepala unit sebagai orang yang bertanggung jawab atas keseluruhan kegiatan unit baik operasional maupun personil, dan juga sistem pengamanan fisik kas yaitu uang kas yang ada di dalam kantor disimpan di dalam lemari besi yang dilengkapi dengan kunci kombinasi angka yang bersifat rahasia, pemeriksaan intern dilaksanakan secara insidentil dan laporan harian dibuat tiap hari kerja sehingga keadaan keuangandapat diketahui.

\section{Saran}

Pengamanan fisik kas yang dilakukan PT. BRI Cabang Tahuna Lebih di tingkatkan lagi keamanannya. Prosedur penerimaan kas yang telah diterapkan PT. BRI Cabang Tahuna agar tetap dipertahankan dan jika memungkinkan ditingkatkan sesuai dengan perkembangan kegiatan dalam perusahaan. Untuk peneliti 
selanjutnya disarankan untuk bisa

dikembangkan penelitian yang berkaitan dengan sistem pengendalian internal khususnya penerimaan kas atau bisa meneliti dengan masalah baru yang ada di bank BRI khususnya pada Cabang Tahuna.

\section{Daftar Pustaka}

Adri A. \&Tirtayati P.S (2015) "Evaluasi Penendalian Internal Atas Siklus Penjualan Dan Penerimaan Kas Pada PT Sinar Surya Terang”

Hasibuan. 2006. Dasar-Dasar Perbankan. PT. Bumi Aksara. Jakarta

Mulyadi. 2008. Sistem Akutansi Pengendalian Intern Salemba Empat. Yogyakarta.

Sujarweni, V. Wiratna. 2015. Sistem Akuntansi. Pustaka Baru Press. Yogyakarta.

Susanto, A. 2013. Sistem Informasi Akuntansi. Lingga Jaya. Bandung. Hal 22-96

Sumurung. P. C. Mario (2015). "Analisis Pengendalian Penerimaan dan Pengeluaran Kas Pada PT. Manado Media Grafika.Hal:262 